\title{
Effect of Feeding Bt Cotton Seed Cake on Nubian Goats Milk Characteristic, Gezira State , Sudan
}

R.H. Jangool

I. Adawi. $\mathbf{A}^{2}$

F. S. Siddig

\section{${ }_{0,2, s}$ University of Gezira, Sudan \\ Licensed: \\ This work is licensed under a Creative Commons Attribution 4.0 License.}

Keywords:

Bt and non Bt-cotton seed cakes

Feed intake

Nubian goats

Milk chatacteristics.

\begin{abstract}
Cotton seed is a traditional protein and energy supplement in the ration of dairy goat. The objective of the experiment is to explore the effect of feeding Bt cotton seed cake on physico-chemical characteristic of goats milk and milk yield.The experiment was conducted in EL Nesheeshiba, Goat Research Center, University of Gezira. Wad Medani, Sudan . Six Nubian goats, were divided into two groups each of three on the basis of their date of kiding. Each goat was housed individually. Each group receive the same concentrate except for the source of cotton seed cake. Where one group received Bt-cotton seed cake and the other Non-Bt cotton seed cake a rate $34 \%$. The result revealed that there was no significant difference $(P>0.05)$ in overall mean between the two groups in physical and chemical composition. But within month were significant different $(P \leq 0.05)$ in chemical and physical composition. The milk yield was significant higher $(P \leq 0.05)$ in all months in the goats feed on Bt cotton seed cake. It is recommended that further studies are needed to investigate the causes of the effects of Bt-cotton seed cake on milk characteristics and any possible harmful effects on human.
\end{abstract}

\section{Introduction}

Cotton (Gossypium spp.) is the major natural textile fiber crop worldwide. In Sudan, cotton has been grown for centuries. The cotton plant is indigenous and a number of its wild relatives exist in various parts of the country. The big jump in cotton cultivation in Sudan was in 1926, which marked the functioning of the Gezira Scheme. Nearly $90 \%$ of the production is exported as raw fiber while the other 10\% is locally consumed [1].Cottonseed meal is the by-product of oil extraction from cotton seeds. As a protein-rich feed, cottonseed meal is a common source of protein for ruminants, notably in cotton-producing areas such as India, China and the USA, where it is used as a partial substitute for soybean meal [2]. Cotton is prone to the lepidopteran insect pests, which causes extensive damage to the crop and results not only the financial losses to the farmers but reduces the much needed cottonseed for the feeding of dairy animals and oil extraction for human consumption. Genetically modified (GM) cotton varieties were released in the Sudan in the year 2012 [3]. In order to provide resistance to the insect's damage, genetically modified (GM) cotton has been developed. GM cotton, having an insect tolerant trait with gene coding for Cry 1 Ac protein derived from Bacillus thuringiensis var. Kurstaki, has been introduced in India for large scale production after evaluation of its safety aspects including that of feeding to the dairy cows [4] who reported the absence of Bt protein in the milk as well in blood plasma of cows fed on Bt cottonseed and the milk production as well as feed intake were similar to those fed on non Bt cottonseed based diet. Similar observations were recorded by Singh, et al. [5] in lactating buffaloes following the feeding of Bt cottonseed based ration in buffaloes.

Feeding of Bt corn grain and corn silage [6] based diets also did not have any adverse effect on milk production performance of dairy cows. Incorporation of cottonseed having Cry $1 \mathrm{Ac}$ and Cry $2 \mathrm{Ab}$ genes in the ration of lactating cows was found safe for lactating cows and their milk production, which was comparable to those fed on isogenic cottonseed without these genes [7, 8].

Generally, in the available literature, effect of feeding Bt Cotton Seed Cake on the milk yield and composition of these products is lacking. Therefore, this research was designed with the following objectives. To investigate the effect of feeding Bt Cotton seed cake on the milk yield and composition of Nubian Goats.

\section{Materials and Methods}

\subsection{The Study Area}

The experiment was conducted in Nesheeshiba, Goat Research Center, University of Gezira, Wad 
Medani, Sudan.

\subsection{Experimental Animals}

A total of six dairy Nubian goats of 18 to $20 \mathrm{Kg}$ live body weight and 1.5 year old were used in the experiment which lasted for four months. The animals were divided into two groups each of three goats according to date of kidding.

\subsection{Housing}

Each goat was identified by an ear tag number and housed in a separate iron cage $(1.5 \times 2 \mathrm{~m})$ fenced by iron bars and shaded by corrugated iron sheet. The cages were provided with water and feed troughs.

\subsection{Feeding of Animals}

The experimental animal were fed formulated concentrated diets (as shown in Table 1) once a day containing, traditional cotton-seed cake (Hamid var.) and Bt cotton -seed cake, in addition to the green fodder and groundnut hay ad lib. Left over concentrate mixture, if any, and residual fodder as well as groundnut hay of individual goats was weighed next morning. DM content of fodder as well as its left over was determined to calculate the DM intake. Fresh clean water was provided freely to each goat three times a day.

Table-1. Percent composition of the concentrate.

\begin{tabular}{l|l|l}
\hline \multicolumn{1}{c|}{ Ingredient } & Bt ration & Non-Bt ration \\
\hline Wheat bran & $\mathbf{\%}$ & $\mathbf{\%}$ \\
\hline Bt cotton seed cake & 17 & 17 \\
\hline Non-Bt cotton seed cake & 34 & - \\
\hline Sorghum & - & 34 \\
\hline Mineral & 45 & 45 \\
\hline Total & 04 & 04 \\
\hline Source: As formulated in the experiment & $\mathbf{1 0 0}$ & $\mathbf{1 0 0}$
\end{tabular}

Source: As formulated in the experiment.

\subsection{Health}

Health of the experimental goats were monitored daily by a veterinarian during the course of the study. At the beginning of the experiment body weight of each goat was recorded prior to their morning, feeding and watering and was again recorded after completion of four month of experimental feeding. Animal live weight was monitored every fifteen days and body condition was score for both goat and kids.

\subsection{Milking and Sampling of Milk for Analysis}

Goats were hand milked once a day at the morning. Each goat was milked in a separate bottle, weighed and recorded. Then stored in a separate tank, which was labelled as Bt or Non Bt at $3{ }^{\circ} \mathrm{C}$ for further (chemical and physical analysis). The samples were taken monthly for 4 month and subjected to chemical and physical analysis.

\subsection{Chemical Analysis}

The samples were analysed for chemical composition (Fat, Protein, Lactose, SNF (percentage) using a lacto scan (serial No 3694 volt, 50/60 hertiz).

\subsection{Physical Analysis}

pH:

The $\mathrm{pH}$ of the milk was measured through electronic digital $\mathrm{pH}$ meter (InolabWTWSeries720). Each milk sample was taken in a beaker and the electrode of the $\mathrm{pH}$ meter was immersed in the sample to determine the $\mathrm{pH}$.

\subsection{Density}

The density of the milk was measured by the lacto scan (serial No 3694 volt, 50/60 hertiz). Feed analysis:

Concentrate feed were analysed for dry matter $(\mathrm{DM})$, crude protein $(\mathrm{CP})$, crude fibre $(\mathrm{CF})$, ether extract $(\mathrm{EE})$ (fat) and ash according to AOAC. 


\section{Results and Discussion}

\subsection{Feed Composition}

Table-2. Chemical composition of the concentrates (\%).

\begin{tabular}{l|l|l|l|l}
\hline & Bt-cotton & Non-Bt cotton & SE & Level of sig. \\
\hline DM & 90.73 & 94.77 & 0.339 & 0.001 \\
\hline Protein & 20.50 & 19.03 & 0.362 & 0.015 \\
\hline Fiber & 10.40 & 12.04 & 0.421 & 0.018 \\
\hline Ash & 7.23 & 8.30 & 0.290 & 0.021 \\
\hline E E & 4.02 & 5.10 & 0.082 & 0.001 \\
\hline \multicolumn{2}{l}{ Source: Analysed according to AOAC }
\end{tabular}

The results in Table 2 indicated a significant different in the analyses of the two concentrate $(\mathrm{P} \leq 0.05)$.. The DM was higher in the Non Bt cotton seed cake fed groups (94.77) than in the Bt cotton seed cake fed groups (90.73). However, protein was higher in Bt than in Non Bt-cotton concentrate, this is in line with the work of Singhal, et al. [4] who found similar results in cows fed Bt and Non Bt ration. Fiber , ash and E E significantly higher in the Non Bt cotton seed cake fed groups (12.04 vs $10.40,8.30$ vs $7.23,5.10$ vs 4.02 respectively ). Also the two concentrates were constructed from the same ingredients and same percentage, the different in the analyses may be due to the cotton seed cake used (Bt or Non Bt) .

\subsection{Feed Intake}

Table-3. Average daily feed concentrate intake $(\mathrm{g})$

\begin{tabular}{l|l|l|l|l}
\hline Month & Bt-cotton & Non-Bt cotton & SE & Level of sig. \\
\hline 1 & 436.38 & 456.62 & 8.25059 & .094 \\
\hline 2 & 461.25 & 451.82 & 3.96600 & .567 \\
\hline 3 & 473.00 & 473.75 & 4.49073 & .924 \\
\hline 4 & 451.00 & 473.00 & 3.67423 & .014 \\
\hline
\end{tabular}

The data in Table 3 shows no significant difference in daily feed intake between the two groups during month 1,2, and 3, this agered with the finding of Calsamiglia, et al. [9] who reported no significant difference in the feed intake of cows fed transgenic corn and non transgenic corn based concentrates ration .Also this results is on line with the work of Singhal, et al. [10] who found no significant different in feed intake of cows fed Bt and non Bt cotton seed cake. However in month 4 the Non Bt group consumed significantly $(\mathrm{P} \leq 0.05)$ higher concentrate than the Bt group.

\subsection{Milk Composition 3.3.1. Milk Fat}

Table-4. Mean Percent milk fat produced from goats fed on Bt and-Non-Bt cotton seed cake.

\begin{tabular}{l|l|l|l|l}
\hline Month & Bt-cotton & Non-Bt cotton & SE & Level of sig. \\
\hline 1 & 4.5300 & 5.0333 & 0.038 & 0.001 \\
\hline 2 & 4.5500 & 5.2267 & 0.035 & 0.000 \\
\hline 3 & 5.0033 & 4.7700 & 0.061 & 0.019 \\
\hline 4 & 5.0400 & 4.7867 & 0.027 & 0.001 \\
\hline Overall mean & 4.7808 & 4.7867 & 0.176 & 0.373 \\
\hline \multicolumn{2}{l}{ Source: Analysed according to AOAC }
\end{tabular}

There was a significant difference $(\mathrm{P} \leq 0.05)$ in milk fat produced from goats fed on Bt and Non Bt cotton seed cake Table 4 in each months of the feeding period. Fat content was higher in Non Bt cotton seed cake fed groups in month 1 and 2 which were 5.0 and 5.2 respectively than in Bt cotton seed cake fed groups which were $4.5,4.5$ respectively. While the fat percent in month 3 and 4 was higher in Bt cotton seed cake which were 5.0 and 5.0 respectively than Non Bt cotton seed cake which were 4.7 and 4.7 respectively. A higher fat percent in the Bt cotton seed cake agreed with the results reported by Calsamiglia, et al. [9] who found a higher fat content in genetically modified corn silage fed cows. On the other hand overall mean was not significantly different. 


\subsubsection{Milk Solid Not Fat}

Table-5. Mean Percent milk solid not fat from goats fed on Bt and Non-Bt cotton seed cake.

\begin{tabular}{l|l|l|l|l}
\hline Month & Bt-cotton & Non-Bt cotton & SE & Level of sig. \\
\hline 1 & 8.95 & 9.00 & 0.169 & 0.797 \\
\hline 2 & 8.64 & 8.92 & 0.020 & 0.001 \\
\hline 3 & 9.28 & 8.95 & 0.012 & 0.001 \\
\hline 4 & 9.30 & 8.86 & 0.012 & 0.001 \\
\hline Overall mean & 9.04 & 8.93 & 0.159 & 0.515 \\
\hline \multicolumn{7}{l}{ Source: Analysed according to AOAC. }
\end{tabular}

As shown in Table 5 generally there was no significant different between the SNF of milk produce from Bt and Non-Bt cotton seed cake in the whole period of the experiment. From the same table SNF produce from Bt cotton seed cake significantly $(\mathrm{P} \leq 0.05)$ increased with time. This agreed with work of Singhal, et al. [4].

\subsubsection{Milk Protein}

\begin{tabular}{l|l|l|l|l} 
Table-6. Mean Percent milk protein from goats fed on Bt and-Non-Bt cotton seed cake. \\
\hline Month & Bt-cotton & Non-Bt cotton & SE & Level of sig. \\
\hline 1 & 3.46 & 3.53 & 0.037 & 0.123 \\
\hline 2 & 3.43 & 3.52 & 0.016 & 0.004 \\
\hline 3 & 3.41 & 3.50 & 0.029 & 0.041 \\
\hline 4 & 3.64 & 3.50 & 0.023 & 0.005 \\
\hline Over mean & 3.48 & 3.51 & 0.053 & 0.624 \\
\hline Source: Analysed according to AOAC
\end{tabular}

Generally there was no significant difference between the mean protein of milk among the two groups. However, there was a trend of increasing protein in Non-Bt group during the second and third month of the period Table 6. This result was not on line with the work of Mohamed [11] who found a higher protein content in cows grazed on Bt cotton crop residues. Also this work agreed with the data reported by Calsamiglia, et al. [9]. Protein content in month 1 and the overall means were not significantly different $(\mathrm{P}>0.05)$ between the two experimental groups. The same results were reported by Singhal, et al. [10]; Singhal, et al. [4] reported no significant difference between the Bt and Non-Bt cotton seed fed cows.

\subsubsection{Milk Lactose}

Table-7. Mean Percent milk lactose from goats fed on Bt and Non-Bt cotton seed cake.

\begin{tabular}{l|l|l|l|l}
\hline Month & Bt-cotton & Non-Bt cotton & SE & Level of sig. \\
\hline 1 & 4.71 & 4.90 & 0.100 & 0.116 \\
\hline 2 & 4.65 & 4.76 & 0.039 & 0.051 \\
\hline 3 & 4.93 & 4.75 & 0.030 & 0.005 \\
\hline 4 & 4.95 & 4.76 & 0.029 & 0.003 \\
\hline Over all mean & 4.81 & 4.79 & 0.084 & 0.840 \\
\hline \multicolumn{2}{l}{ Source: Analysed according to AOAC. }
\end{tabular}

Milk lactose almost followed the trend of protein. In general both Bt and Non-Bt cotton seed cakes had no significant effect on milk lactose concentration. This results were not on line with the work of Calsamiglia, et al. [9] who recorded a significant difference in lactose content in cows fed transgenic and non transgenic corn . However in month 1 and overall means, lactose content was similar $(\mathrm{P}>0.05)$ in the both experimental groups. This results agree with the findings on $[4,10]$.

\subsubsection{Milk Ash}

Table-8. Mean Percent of ash produced from goats fed on Bt and Non-Bt cotton seed cake.

\begin{tabular}{l|l|l|l|l}
\hline Month & Bt-cotton & Non-Bt cotton & SE & Level of sig. \\
\hline 1 & 0.77 & 0.56 & 0.116 & 0.147 \\
\hline 2 & 0.56 & 0.65 & 0.034 & 0.059 \\
\hline 3 & 0.86 & 0.69 & 0.046 & 0.021 \\
\hline 4 & 0.70 & 0.58 & 0.060 & 0.127 \\
\hline Over mean all & 0.72 & 0.62 & 0.0701 & 0.194 \\
\hline \multicolumn{2}{l}{ Source: Analysed according to AOAC. }
\end{tabular}

Source: Analysed according to AOAC 
Except for in month three of the experiment, ash content was statistically similar in both group of the animals (Bt vs Non-Bt feed group). These results also were on line with the work of Mohamed [11].

\subsubsection{Milk Density}

Table-9. Mean percent of milk density from goats fed on Bt-cotton and Non-Bt cotton seed cake.

\begin{tabular}{|c|c|c|c|c|}
\hline Month & Bt-cotton & Non-Bt cotton & SE & Level of sig. \\
\hline 1 & 30.7867 & 34.1300 & 0.017 & 0.001 \\
\hline 2 & 30.4000 & 30.8000 & 0.270 & 0.214 \\
\hline 3 & 32,2800 & 30.9833 & 0.0900 & 0.106 \\
\hline 4 & 32.1500 & 31.0100 & 0.029 & 0.001 \\
\hline Over all mean & 31.404 & 31.730 & 0.931 & 0.700 \\
\hline
\end{tabular}

Milk density Table 9 was not significantly different between the two groups. However a very narrow range though it is significant was seen in month one where Non-Bt group had higher density and in month four where it had lower density.

\subsubsection{Milk pH}

Table-10. $\mathrm{pH}$ of milk produced from goats fed on Bt-cotton and-Non-Bt cotton seed cake.

\begin{tabular}{l|l|l|l|l}
\hline Ph & Bt-cotton & Non-Bt cotton & SE & Level of sig. \\
\hline & 6.08 & 6.06 & .03125 & 0.538 \\
\hline
\end{tabular}

The results indicted no significant difference $(\mathrm{P}>0.05)$ between the two experimental groups Table 10. These results agreed with the data presented by Mohamed [11].

\section{Conclusions}

It could be concluded that feeding on Bt cotton seed cake had no affect, on milk chemical and physical properties. However more investigations are needed as our experiment included small number of animals.

\section{References}

[1] A. B. El Fadil, "Report on Sudan cotton research and production," 2009.

[2] b. O, G.W., "Performance of cattle given crop residues supplemented with high quality forages and agroindustrial by products," Livestock Research for Rural Development, vol. 4, pp. 64- 73, 1992.

[3] A. M. Ali and 1. Zhang, "A proposal for the release of a hybrid and a variety of Bt cotton (G. hirsutum) for production in Sudan," Paper Presented to the National Variety Release Committee. March 2012. Khartoum, Sudan, 2012.

[4] K. K. Singhal, A. K. Tyagi, Y. S. Rajput, and S. Prasad, "Effect of feeding cottonseed produced from Bt cotton cultivar on feed intake, production and composition of milk in dairy cows," Report submitted to Metahelix Life Sciences Ltd, Bangalore. National Dairy Research Institute, Karnal2008.

[5] M. Singh, D. P. Tiwari, A. Kumar, and M. R. Kumar, "Effect of feeding transgenic cottonseed vis-a-vis nontransgenic cottonseed on haematobiochemical constituents in lactating Murrah buffaloes," Asian-Australasian Journal of Animal Sciences, vol. 16, pp. 1732-1737, 2003.

[6] J. Folmer, R. Grant, and J. Beck, "Use of Bt corn silage and grain by lactating dairy cattle," Dairy Report (20012002) University of Nebraska, Lincoln, 2001.

[7] A. R. Castillo, M. R. Gallardo, M. Maciel, J. M. Giordano, G. A. Conti, M. C. Gaggiotti, O. Quaino, C. Gianni, and G. F. Hartnell, "Effects of feeding rations with genetically modified whole cottonseed to lactating dairy cows," Journal of Dairy Science, vol. 87, pp. 1778-1785, 2004.

[8] K. K. Singhal, R. S. Kumar, A. K. Tyagi, and Y. S. Rajput, "Evaluation of Bt cottonseed as protein supplement in the ration of lactating dairy cows," Indian Journal of Animal Sciences, vol. 76, pp. 532-37, 2006a.

[9] S. Calsamiglia, B. Hernandez, G. F. Hartnell, and R. Phipps, "Effects of corn silage derived from a genetically modified variety containing two transgenes on feed intake, milk production, and composition, and the absence of detectable transgenic deoxyribonucleic acid in milk in Holstein dairy cows," Journal of Dairy Science, vol. 90, pp. 4718-4723, 2007.

[10] K. K. Singhal, R. S. Kumar, A. K. Tyagi, and Y. S. Rajput, "Evaluation of Bt cottonseed as protein 282 supplement in the ration of lactating dairy cows," Indian Journal of Animal Sciences, vol. 76, pp. 532-537, 2006.

[11] A. H. Mohamed, "Effects of grazing on Bt cotton residues on feed intake and milk characteristics of dairy cows in Gezira State, Sudan," MSc Thesis, University of Gezira, 2016. 